\title{
Psycholinguistic Problem Field of Studies of the Social Online Networks Discourse
}

\section{Проблемне поле психолінгвістичних досліджень дискурсу соціальних онлайн-мереж}

\author{
Vitalii Bochelyuk ${ }^{1}$ \\ Dr. in Psychology, Professor, \\ Head of the Department \\ of Psychology
}

\author{
Віталій Бочелюк ${ }^{1}$ \\ доктор психологічних наук, \\ професор, завідувач кафедри \\ психології
} E-mail: vitalik.psyhol@ukr.net
orcid.org/0000-0001-8727-3818

Nikita Panov ${ }^{2}$

Ph.D. in Psychology,

Assistant Professor
Микита Панов 2

кандидат психологічних наук, доцент

E-mail: nikita.psyhol@ukr.net orcid.org/0000-0002-5085-8895

${ }^{1}$ Zaporizhzhya National

Technical University

64, Zhukovsky Str., Zaporozhye, Ukraine, 69063

${ }^{2}$ Municipal Institution of Higher Education «Khortytsia National Educational Rehabilitation Academy» of Zaporizhzhia Regional Council $\triangle 59$, Naukove Mistechko Str. (Khortytsia Island), Zaporizhzhia, Ukraine, 69017
1 Запорізький національний технічний університет $\triangle$ вул. Жуковського, 64, м. Запоріжжя, Україна, 69063

${ }^{2}$ КВНЗ «Хортицька національна навчально-реабілітаиійна академія» $30 P$

$\triangle$ вул. Наукове містечко

(о. Хортиця), 59, м. Запоріжжя, Україна, 69017

Original manuscript received April 05, 2018

Revised manuscript accepted October 15, 2018

ISSN 2309-1797 (print) / 2415-3397 (online) 


\section{ABSTRACT}

The research paper deals with theoretical and applied analysis of communication problems in social online networks. It is shown that due to the specifics of the communication channel a virtual community with unique linguistic, cultural and psychological properties are formed (in this case described the change in the landscape of using Internet resources which arose as a result of deployment of the socio-political crisis in Ukraine). The phenomenon of fragmentary brikolage thinking is described, which arises as a result of influence of the hypertext structure and information load of the Internet environment. The nature of network communication gives grounds to speak about the formation of a special form of speech - oral in terms of essence and printed in terms of realization. The personality is presented in the online discourse in a reduced form: as a set of text and visual messages produced by it. Typical forms of communicative activity in the network environment that have a diagnostic and prognostic value are described. The topical prospects of psycholinguistic studies of the discourse of social online networks are identified: the problem of perception and interpretation of text messages; the problem of the relationship between the technological capabilities of the communication channel and the forms of user communicative behavior: the problem of selfpresentation and design of effective communications; the problem of adequate "reading" of the linguistic personality being the partner in communication, recognition of markers of certain psychological disorders; the problem of manipulative and mobilizing influence, the need to develop critical thinking skills regarding perceived information, its falsifications and distortions; the problem of influence of online communication on a particular person, his/her outlook and behavior, as well as on society as a whole; the importance of information technology in the ontogenesis of speech. The methodological problem of developing and improving tools for evaluating human behavior on the Internet is presented through the analysis of texts.

Key words: Internet discourse, virtual communication, social network, online message design, self-presentation, manipulation, communicative ethics.

\section{Вступ}

Перебування в онлайн-мережах - невід'ємна ознака сучасної людини незалежно від іiі віку, статі та соціально-професійного статусу. За даними Gemius Audience (2017) в Україні 22,7 млн. активних Інтернет-користувачів, в середньому кожен з них проводить в мережі 7-8 годин на тиждень. Онлайн-світ опосередковує реальну поведінку та діяльність людини. Для активної молоді особиста сторінка соціальної мережі $\epsilon$ головним засобом спілкування, 
Psycholinguistic Problem Field of Studies of the Social Online...

самопрезентації, професійного просування, виникнення й закріплення ділових та інтимних міжособистісних контактів. Водночас, молоді амбіційні професіонали - головні створювачі так званого контенту: змістовного інформаційного наповнення, що виступає предметом інтернет-спілкування. Вони завзято включені у віртуальний комунікативний простір (відвідують власні сторінки десятки разів на день залежно від активності аудиторії), розуміють його динаміку, цікавляться закономірностями розповсюдження i функціонування інформації в інтернет-мережі. Старші особи мають власний акаунт і регулярно його використовують, але рідше створюють авторський контент та вступають у віртуальний дискурс. Для них соціальна онлайн-мережа $є$ важливим способом підтримки родинних стосунків та включеності в загальну канву суспільного життя (через поширеність електронних 3МI).

В останні десятиріччя найбільш популярними онлайнплатформами, що використовувались українцями, були соціальні мереж ВКонтакті, Facebook, Instagram, Twitter, Однокласники та Linkedin. Всередині кожної з них сформувалася соціальна спільнота 3 унікальними особливостями комунікації та правилами взаємодії. В цьому інформаційному середовищі виділялися лідери думок, велися дискусії та формувався світогляд особистості. Кризова політична ситуація призвела до обмеження спектру доступних Інтернет-ресурсів - після заборони у травні 2017 р. ряду російських сайтів ландшафт користування соціальними мережами докорінно змінився. Сьогодні більшість дорослих та освічених українців використовують онлайн-сервіс Facebook; серед молоді популярний Instagram, котрий поступово із додатку обміну зображеннями перетворився в багатофункціональну платформу спілкування й бізнесу. Водночас, зросла затребуваність конфіденційності та безпеки спілкування, про що свідчить популярність новоствореної мережі Telegram.

Слід відзначити, що через інноваційність і динамічність Інтернет-середовища всі соціально-психологічні процеси в ньому мають надзвичайно прискорений характер, тому традиційні методи наукового дослідження часто не в змозі виділити ключові події та дати їм належну інтерпретацію. Складається специфічна ситуація, коли наукова спільнота здатна фіксувати та ретроспективно пояснювати, але не в змозі своєчасно прогнозувати або контролювати 
процеси. Тим не менше, слід відмітити теоретичну і практичну значущість праць 3 психології комп'ютерно-опосередкованого спілкування (Войскунский, 1990; Тихомиров, 1993; Белинская, 2000); 3 питань соціалізації і самопрезентації особистості у віртуальному просторі (Шевченко, 2002; Шебанова, 2014); щодо впливу Інтернеткомунікації на суспільні та психолінгвістичні процеси (Горошко, 2008). Але невпинний розвиток онлайн-технологій ставить перед дослідниками нові виклики.

Мета статі - здійснити аналіз проблемного поля віртуальної комунікації в соціальних онлайн-мережах та виділити найактуальніші перспективи психолінгвістичних наукових досліджень.

\section{Методи і методики дослідження}

Для написання статті використовувався комплекс теоретичних методів, узагальнення даних психолінгвістичних джерел. Автори здійснили тематичний аналіз досліджень віртуального дискурсу в наукових публікаціях та дисертаціях останніх двох десятиліть. В основі виділення проблемного поля - рефлексія власного професійного досвіду.

\section{Результати та дискусії}

Оскільки докорінно змінилося зовнішне інформаційне поле, в якому формується особистість, сьогодні говорять про формування нової культури та нового типу мислення - образно-візуального, кліпового, бриколажного (К. Леві-Стросс, Ж. Дерріда). Повсякденна зануреність в онлайн-середовище призвела до того, що традиційний текст 3 його логічно-послідовною структурою замінюється гіпертекстом - багаторівневою системою посилань, сукупністю мікро-текстів $з$ нелінійною логікою.

Особливість відповідного типу мислення полягає у якнайширшому охопленні інформації з поверховим, фрагментарним заглибленням в сутність та сенс повідомлення. Н. Карр описує цей феномен наступним чином: «Я вже не думаю так, як думав раніше. Особливо це помітно при читанні. Раніше я з легкістю занурювався в книгу або довгу статтю. Мозок захоплювався розповіддю або поворотами дискусії, і я годинами бродив довгими шляхами прози. Тепер таке трапляється рідко. Після двох-трьох сторінок увага починає розсіюватися, з'являється якась метушливість, я втрачаю 
нитку, починаю шукати, чим би ще зайнятися. Таке відчуття, що мені постійно доводиться підтягати свій неслухняний мозок назад до тексту. Глибоке читання, яке раніше відбувалося цілком природно, перетворилося в боротьбу» (Carr, 2008). Подібні відчуття знайомі більшості наших сучасників. Інтернет-користувачі не читають в традиційному розумінні цього слова; 3'являються нові форми сприйняття: людина горизонтально «пробігає очима» по заголовкам, абзацам тексту в пошуках цікавої інформації. Ми вважаємо, що описані явища відображують природні процеси адаптації психіки до функціонування в умовах перенавантаження інформаційного простору та його гіпертекстової організації. В даний час ми $\epsilon$ свідками формування нового типу мислення людини, переваги та недоліки якого будуть з'ясовані після накопичення відповідних емпіричних даних.

Ще двадцять років тому О.К. Тихомиров писав про необхідність доопрацювання теорії Л.С. Виготського з урахуванням впливу діалогових інформаційних систем на онтогенез мислення (Тихомиров, 1993). Комп'ютерні технології в цьому сенсі виступають водночас як зовнішнє знаряддя праці і як психологічне знаряддя, детермінуючи внутрішні психічні процеси. Від впливом цього знаряддя змінюються знакові системи та характеристики практичної діяльності, відповідно змінюються властивості мови, мислення, пам'яті, уяви. Нові технології пов'язані 3 функціями зовнішньої i внутрішньої мови. Виникає спілкування, опосередковане комп'ютером, а також діалог 3 самими інформаційними технологіями. Згадаємо в цьому сенсі про активне використання в сучасних месенджерах чат-ботів, коли людина в прямому сенсі спілкується з роботом, комп'ютерною програмою, і при цьому може навіть не усвідомлювати цього.

Крім того, особливості мережевого спілкування дають підстави говорити про формування особливої форми мовлення. O.Є. Войскунський вказує, що опосередкування виконавчої стадії спілкування комп'ютером формує нову специфічну форму мовної комунікації, що об'єднує елементи усного й писемного, діалогічного та монологічного мовлення, а також аутокомунікації. Важливе міркування про те, що Інтернет - це не тільки лінії зв'язку i інформаційні масиви, але перш за все це люди. Особистість представлена онлайн не у всій своїй суб'єктності, а редуковано: 
як набір продукованих нею самою (або іншими людьми про неї) текстів: самоописів та реплік в публічних онлайн-діалогах. Оскільки людина скорочена до набору вербальних повідомлень різного ступеню істинності і детальності, то саме на ці відомості спираються співрозмовники для орієнтування в потенційному комунікативному партнері (Войскунский, 1990, 2001).

Психологи, соціологи та філологи досить давно вказують на віртуальну мовну особистість як новий тип адресата і адресанта, якому притаманні зміщені акценти світосприйняття. Комунікації у віртуальних спільнотах формують своєрідні ідентичності, які неможливо і навіть небажано проявляти в реальному житті (Шевченко, 2002). Деякі типи віртуальних особистостей $\epsilon$ проявами особистісних порушень (наприклад, агресивність або відкрита гіперсексуальність: зустріч 3 такими особами становить реальну небезпеку мережевого спілкування). Водночас вони дозволяють реалізувати ряд незадіяних здібностей, фрустрованих потреб людини, експериментувати 3 різноманітними проявами «Я» та комунікативними тактиками, отримуючи новий досвід (психотерапевтичний ефект онлайн-спілкування).

Масштабні дослідження (Ahn \& Shin, 2013) довели неоднозначність впливу онлайн-медіа на психологічне благополуччя особистості. Соціальне використання цих ресурсів обмежене прагненням до зв'язків 3 іншими людьми; вони доповнюють особистісне спілкування та запобігають виникненню соціальної ізоляції. При цьому Інтернет приваблює самотніх людей - в першу чергу, через комунікативний потенціал та змінені соціально моделі взаємодії, що дозволяють зменшити негативні настрої, пов'язані із самотністю (Morahan-Martin \& Schumacher, 2003). Важливо, що людина самостійно контролює рівень своєї «невидимості» і анонімності в онлайн-середовищі. Проблема творення віртуальної особистості, популярна наприкінці 1990-х років, зараз актуалізується в новій якості.

Одним $з$ найпопулярніших методів сучасної психолінгвістики $\epsilon$ дискурс-аналіз, сфокусований на сукупності текстів, які продукуються в життєвих практиках - зокрема, в онлайн-взаємодії. В цьому розумінні дискурс постає самостійним смисловим полем, це символічна реальність, що розвивається за певною динамікою, має власні соціальні закони і правила поведінки (Філліпс \& 
Йоргенсен, 2009). Визнані характеристики онлайн-дискурсу: ретиальний характер спілкування, фізична непредставленість i водночас, комунікативна близькість співрозмовників, своєрідне протікання процесів міжособистісного сприйняття, компенсаторна віртуальна емоційність (Белинская \& Жичкина, 2000). При цьому ряд згадуваних в ранніх наукових публікаціях властивостей: анонімність, нерегламентованість і зниження соціальних ризиків спілкування, сьогодні є суперечливими.

Серед лінгвокультуральних особливостей віртуального дискурсу (Лутовинова, 2009) описані новітні надбані жанри: флейм (вербальна війна, суперечка заради суперечки), мережевий флірт, креатив, флуд (беззмістовне повідомлення, марнослів'я), спам, послання, прецедентні висловлювання, тексти, персонажі. Виділені комунікативні стратегії, котрі сприяють соціалізації і самопрезентації особистості: пошукова, що організує, що позиціонує, що пояснює, що оцінюе, що сприяє, що дискредитує. В цьому сенсі становить практичний інтерес аналіз типових комунікативних патернів активності користувачів в онлайн-мережі (Пильгун, 2015):

1. Інформативно-аналітичний патерн використовують просунуті користувачі соціальних мереж, які активно створюють події та беруть участь в комунікації, застосовують всі технічні можливості програмного каналу спілкування, цікавляться новими функціями і активно застосовують їх.

2. Комунікативно-гедоністичний патерн застосовують особи 3 високою потребою в спілкуванні, які вважають онлайн-простір важливою формою соціальної комунікації. Вони активно створюють повідомлення, читають та пишуть відгуки, застосовують різні технічні функції та інструментарій для розширення кола спілкування і отримання задоволення від комунікації.

3. Презентативний патерн має за мету підтримки або створення іміджу в Інтернет-просторі. Користувачі сконцентровані на найбільш ефективних способах використання онлайн-функцій для побудови потрібного образу.

4. Імітаційний патерн використовується для заміни offlineспілкування. Такі особи активно переглядають, але рідко коментують чужі профайли, можуть створювати і поширювати власні матеріали. Більше, ніж для інших груп характерно прагнення до візуалізації, що дозволяє мінімізувати витрати на інтерпретацію інформації. 
5. Споживчий патерн застосовують для пасивної присутності в мережевому середовищі; він дозволяє отримувати інформацію, відстежувати події, односторонньо брати участь у взаємодії, не надаючи даних про себе.

Дана класифікація є найбільш сучасною, вона дає пояснює цілі і засоби комунікації людини в онлайн мережі, дозволяє прогнозувати деякі аспекти поведінки. Але виділені патерни потребують уточнення у зв'язку із зміною ландшафту користування соціальними Інтернет-ресурсами.

Наразі використання соціальних онлайн-мереж стає більш професійним, користувачі набувають досвід віртуального дискурсу, компетентність у використанні технічних каналів комунікації, обирають для себе найбільш зручні засоби і форми спілкування в різних ситуаціях. Динаміка розвитку соціальних мереж та засобів онлайн-комунікації формує поле актуальних проблем, для вирішення яких доцільно залучити методологію та теоретичні напрацювання психолінгвістики.

1) Проблема сприйняття та інтерпретації повідомлень різного характеру. Онлайн-комунікація, будучи концептуально усною, реалізується в письмовій формі, в результаті чого виникає новий тип дискурсу - усно-писемний максимально неформальний, лаконічний та емоційно-насичений. В умовах відсутності невербальної стимуляції, користувачі вигадують оригінальні способи посилення значущості власного тексту: ЗБІЛЬШЕННЯ РЕГІСТРУ що розцінюється читачем як посилення інтонації, навіть крик; свідоме нехтування правилами синтаксису та пунктуації; використання емотиконів як спосіб передачі емоційного стану; широке використання ненормативної і нецензурної лексики. Серед останніх тенденцій віртуальної комунікації - тісне поєднання текстового та візуального повідомлення. Будь-який допис в соцмережі супроводжується картинкою, що додатково розкриває його зміст (власною або запозиченою), здебільшого це позитивні емоційнонавантажені візуальні образи. При відсутності картинки-образу повідомлення додатково оформлюється за допомогою кольорового фону та шрифту, що сприяє залученню уваги читача, робить його вагомішим, розкриває емоційний стан автора. 3 іншого боку, самодостатні i промовисті Instagram-картинки супроводжуються специфічним гіпертекстом - \#хештегами, що сприяють їх 
Psycholinguistic Problem Field of Studies of the Social Online...

сприйняттю та поширенню в мережі. Ми спостерігаємо, що текстова частина повідомлень стає більш лаконічною - автор мусить за допомогою декількох фраз розкрити зміст інформації у цікавій та доступній для читачів формі. В немалому ступені такому дизайну повідомлень сприяє поширення мобільного інтернет-доступу: друк тексту на смартфоні не $є$ зручним, тому партнери по спілкуванню обмежуються короткими змістовними репліками.

Bсе це має численні, доки малопомітні наслідки на різних рівнях функціонування мови та взагалі, психіки (наприклад, вже відмічений феномен бриколажного мислення, зменшення здатності послідовного та вдумливого читання текстів великого обсягу, труднощі розпізнавання i сприйняття емоцій дітьми дошкільного віку). Особливо важливе в цьому сенсі формування мовленнєвої культури дітей та підлітків, що зазнають найбільш неконтрольованого впливу мережевої субкультури.

Конкретні напрямки та пропоновані методи дослідження: a) психолінгвістичний аналіз змісту онлайн-дискусій та особистих акаунтів 3 метою верифікації функціонально-мовленнєвих моделей, синтаксично-граматичної структури; б) спостереження за природною полікомпонентною поведінкою читача при взаємодії 3 гіпертекстом (фіксація часу читання, вербальних і невербальних реакцій, перехід гіперпосиланнями в бокові гілки дискусії, запис руху очей i т.д.) в) спостереження за виникненням і розвитком конфліктних ситуацій, непорозумінь в онлайн-дискурсі; г) інтерпретативний аналіз. Завдяки тривалому збереженню продуктів діяльності користувачів, онлайн-мережі надають широкі можливості регістрації i наступного аналізу ряду об'єктивних параметрів (тематика та зміст висловлювань, структура письмової мови, реакція аудиторії, способи маркування емоцій тощо).

2) Проблема технологічних можливостей та обмежень продукування текстів в середовищі онлайнових соціальних мереж. Технічні особливості каналу комунікації $є$ визначальною характеристикою онлайн-спілкування. При цьому будь-яка зміна програмного забезпечення неминуче викликає трансформації поведінки користувачів. Серед цікавих в контексті психолінгвістичного підходу інновацій - трансформація алгоритмів поширення інформації в соціальній мережі Facebook, спрямована на стимуляцію інтерактивної сторони спілкування. Формула «коментарі 
важливіші за лайки» призвела до того, що автори контенту стали активно спонукати аудиторію до включеної взаємодії, шукати способи викликати відгуки у вигляді текстових повідомлень, коментарів. Важливою тенденцією $є$ політика Facebook щодо просування відео-контенту. Пріоритет показу живих відеотрансляцій (технічний аспект) повернув в онлайн-середовище безпосереднє мовне спілкування (принаймні 3 боку актора), що складає конкуренцію традиційному текстово-візуальному способу самовираження.

Конкретні напрямки та пропоновані методи дослідження: формувальний експеримент 3 метою навчання користування технічними засобами віртуальної реальності для досягнення комунікативної мети і вирішення власних завдань в професійній i суспільній діяльності, для навчання, творчості або відпочинку.

3) Проблема самопрезентації та дизайну власних повідомлень, що передбачає осмислення себе, власного досвіду, можливостей ефективної взаємодії 3 іншими людьми у віртуальному просторі. Актуальним трендом $є$ формування «Я-бренду»: усвідомлений підбір матеріалів, що сприяють побудові привабливого іміджу особистості. При цьому створювачі контенту зацікавлені у якомога більш ефективному впливі повідомлення - заради поширення інформації, залучення нової аудиторії, стимулювання конкретних дій читачів (піти за посиланням, зареєструватись, купити товар або послугу). 3 іншого боку, презентаційні практики та самопроектування особистості у віртуальному дискурсивному просторі $\epsilon$ першим продуктивним кроком до втілення бажаних властивостей і поведінкових патернів в реальному житті.

Конкретні напрямки та пропоновані методи дослідження: контент- та інтент-аналіз вербального та невербального змісту особистих профілів 3 метою класифікації способів і тактик самопрезентації в онлайн-мережі.

4) Партнери в онлайн-комунікації свідомо або неусвідомлено творять свою віртуальну ідентичність, орієнтуючись на уявлення про психологічні особливості тих, кому адресоване послання. Ці процеси розповсюджені і в безпосередній взаємодії, але дистантність та опосередкованість спілкування надає для цього зовсім інші можливості. Все вищеперераховане породжує феномен «наративної маски» та міфологізацію Я-образу при текстотворенні. Відповідно, 
постає проблема адекватного «зчитування» мовної особистості, психологічного портрету партнера по спілкуванню, розпізнавання маркерів певних особистісних характеристик та порушень (лексика, знання граматики, використання «смайлів» та скорочень, тематика i стилістика повідомлень, тощо). Прикладом вдалого наукового рішення цієї проблеми може слугувати аналіз гендерних особливостей текстових повідомлень в Інтернет-комунікації (Горошко, 2006); дослідження мережевих псевдонімів та способів саморозкриття осіб, хворих на анорексію (Шебанова, 2014).

Конкретні напрямки та пропоновані методи дослідження: застосування семантичного диференціалу для оцінки образу віртуального партнера; природний експеримент з фіксацією реакцій аудиторії на різноманітні способи самопред'явлення.

5) Проблема маніпулятивного та мобілізаційного дискурсу соціальних медіа в умовах кризового суспільства та інформаційної війни. Сучасна людина повинна цілеспрямовано формувати у себе навички критичного мислення стосовно сприйнятої інформації, ii фальсифікації та можливих перекручувань. Іншим аспектом проблеми $\epsilon$ розповсюдження недостовірної інформації 3 метою отримання комерційного прибутку (проплачені відгуки щодо товарів та послуг) та випадки шахрайства через благочинні акції.

Конкретні напрямки та пропоновані методи дослідження: a) експертна оцінка для розпізнавання маніпулятивних впливів, б) створення сугестивних повідомлень та експериментальна референціальна комунікація, тобто контрольоване вкидання інформації певного змісту, форми, облаштування ситуації спілкування та фіксація реакції онлайн-аудиторії (з ретельним дотриманням етики наукового дослідження); в) дискурс-аналіз висловлювань лідерів думок 3 метою виявлення ефективних тактик впливу.

6) Проблема впливу онлайн-текстів на окрему особистість, іiі світогляд та поведінку, а також на суспільство в цілому. Стосовно мовного дискурсу можемо відмітити, що в буденну мову сучасної людини давно увійшли такі поняття як «зафрендити», «забанити», «репост», «лол» та інші конструкції віртуальної комунікації. Безсумнівно, що загальний вплив на культуру спілкування, на функціонування мови є більш глибоким та багатогранним. 
Так, очевидний вплив соціальних мереж на змістовний бік повсякденності, що є основним наповненням їхнього контенту. На наших очах формується нове усвідомлення буденності: звичним предметом публікацій є домівка, побут, родина, робота, дозвілля, їжа, піклування про власне здоров'я, завдяки чому ці сторони життя наповнюються особливим сенсом - самоідентифікаційним, ціннісним, естетичним. Вже помітно, що побутова тематика і мова впевнено увійшли у визнані літературні жанри: успішні пропозиції книжкового ринку представляють собою збірки коротких творів, які були вперше опубліковані та отримали популярність саме в онлайнспільноті (Слава Се, Ольга Котрус, Павло Белянський і баг. інших). Це новий соціально-культурний феномен, що потребує окремого вивчення. 3 іншого боку, саме в онлайн-спілкуванні проявляються i функціонують найбільш потужні «лідери думок». Популярні мережеві персонажі поширюють свій стиль мовлення, спосіб мислення, свої цінності та картину світу на необмежено широку та зацікавлену аудиторію.

Конкретні напрямки та пропоновані методи дослідження: масштабний збір та аналіз продуктів віртуального дискурсу лідерів думок; побудова семантичних просторів в різних віртуальних спільнотах 3 метою «ціннісного зрізу буденності»; аналіз представленості життєвих подій в онлайн-хроніках.

7) Проблема впливу інформаційних технологій на онтогенез мовлення та розвиток психіки в дитячому віці. Конкретні напрямки методи дослідження: а) порівняльне дослідження 3 метою виявлення особливостей мовного та психосоціального розвитку дітей з різними моделями поведінки в онлайн-середовищі; б) регістрація зміни параметрів усного та писемного мовлення внаслідок обмеження користування онлайн-мережами.

Переконливо доведена висока достовірність результатів психологічних досліджень, отриманих через онлайн-канали. Дослідники в усьому світі визнали корисність соціальних мереж як інструменту спостереження за поведінкою користувачів, поля природних експериментів, перевірки гіпотез та залучення учасників досліджень. Хоча досі невизначені найбільш ефективні інструменти ля здійснення таких досліджень (Wilson, Gosling \& Graham, 2012). Функціонування мови в особливому комунікативному середовищі Інтернету потребує вивчення багатошарової (текстово-аудіо- 
візуальної) семіотичної системи, а також розширення парадигм психолінгвістичного аналізу (Горошко, 2008). Методологічна проблема полягає в необхідності розробки нових компетентних інструментів оцінки поведінки людини в Інтернет-мережі, вивчення вищих психічних функцій через аналіз текстів в онлайн-спілкуванні, методів експериментального дослідження мислення людини в діалозі з інформаційними технологіями.

\section{Висновки}

У психолінгвістичний літературі склалася традиція протиставляти віртуальний дискурс реальному, розглядати його як неінституційну форму спілкування, народжену технічними засобами зв'язку та занурену в них. Проте сьогодні вже неможливо ігнорувати той факт, що фокус соціальної активності людей змістився в онлайн-середовище. Відповідно, формується специфічна віртуальна спільнота з унікальними мовними, культурними та психологічними властивостями. Основним засобом спілкування тут $€$ короткі друковані повідомлення, що реалізують неформальну усно-писемну форму мовлення, а також емоційно-забарвлені візуальні стимули, які його супроводжують. Комунікативна ситуація зумовлює різноманіття нових моделей мовного дискурсу: процесуальних, стилістичних, текстових, синтаксичних, семіотичних, функціональнокомунікативних. Фізична непредставленість партнерів зумовлює елемент гри, міфотворчості, а також експерименти з ідентичностями і маніпуляції в онлайн-спілкуванні.

У статті обгрунтовано перелік актуальних соціальнопсихологічних проблем, для вирішення яких доцільно залучити теорію та методологію психолінгвістики: сприйняття та інтерпретації повідомлень різного характеру; технологічні можливості та обмеження творення текстів у середовищі онлайнових соціальних мереж; проблема самопрезентації і мережевої ідентичності, що передбачає осмислення себе і власного досвіду взаємодії з іншими; проблема маніпулятивного, сугестивного та мобілізаційного дискурсу соціальних медіа; вплив онлайн-текстів на світогляд та поведінку як окремої особистості, так і суспільства в цілому; вплив на онтогенез мовлення та розвиток психіки в дитячому віці. Все це потребує наукового пояснення та зумовлює актуальні перспективи міждисциплінарних досліджень, що поєднують лінгвістичну, 
Проблемне поле психолінгвістичних досліджень дискурсу...

психологічну та соціологічну методологію. Глобальною метою цієї роботи $є$ забезпечення психологічної безпеки та розвиток комунікативної компетентності мовної особистості у віртуальному дискурсі.

\section{Література}

Войскунский, А.Е. Преобразование общения, опосредствованного компьютером : автореф. дисс. ... канд. психол. наук : 19.00.01. Москва : МГУ им. М.В. Ломоносова, 1990. 26 с.

Войскунский, А.Е. Развитие речевого общения как результат применения Интернета. Социильные и психологические последствия применения информационных технологий : материалы международной интернетконференции на информационно-образовательном портале www.auditorium/ru (20.03-14.05.2001) / под ред. А.В. Войскунского. Москва, 2001. С. 232-242.

Горошко, Е.И. Интернет-коммуникации в гендерном измерении. Вестник пермского университета «Язык - культура - циивилизация». 2006. Вып. 3. C. 219-229.

Горошко, Е.И. Психолингвистика Интернет-комммуникаций. Bonpocbl психолингвистики. 2008. № 7. С. 5-12.

Пильгун, М.А. Основные коммуникативные паттерны в русскоязычной сетевой среде. Вопросы психолингвистики. 2015. № 2(24). С. 166-176.

Тихомиров, О.К. Информационный век и теория Л.С. Выготского. Психологический журнал. 1993. Том 14, № 1. С. 111-119.

Шебанова, В.І. Діагностика особистісної самопрезентації хворих на нервову анорексію методом контент-аналізу. Перспективні напрямки розвитку сучасних педагогічних $i$ психологічних наук : зб. тез Міжнародної науковопрактичної конференції (14-15 березня, 2014). Харків : Центр педагогічних досліджень, 2014. С. 83-87.

Филлипс, Л., Йоргенсен, М. Дискурс-анализ. Теория и метод / пер. с. англ. Харьков : Гуманитарный Центр, 2008. 352 с.

Лутовинова, О.В. Лингвокультурологические характеристики виртуального дискурса : дисс. ... доктора филол. наук : 10.02.19. Волгоград, 2009. 519 с.

Белинская, Е.П., Жичкина, А.Е. Современные исследования виртуальной коммуникации. Образование и информационная культура. 2000. С. 395-428.

Шевченко, И.С. Вариативность самопрезентации личности в Интернет-общении : дисс. ... канд. психол. наук : 19.00.01. Казань, 2002. 170 с.

Ahn, D., \& Shin D.-H. (2013). Is the social use of media for seeking connectedness or for avoiding social isolation? Mechanisms underlying media use and subjective wellbeing. Computers in Human Behavior, 29, 2453-2462. doi:10.1016/j. chb.2012.12.022

Boyd, D.M., \& Ellison, N.B. (2008). Social network sites: Definition, history, and scholarship. J. Comput.-Mediat. Commun, 13, 210-230. doi: 10.1111/j.10836101.2007.00393.x

Carr, N.G. (2008). The Big Switch: Rewiring the World, from Edison to Google. New York, London : W.W. Norton \& Company.

Gemius Audience. Internet audience of Ukraine in September 2017 (October 19, 2017). Retrieved from https://www.slideshare.net/LesyaPrus/internet-audience-ofukraine-in-september-2017 
Morahan-Martin, J., \& Schumacher, P. (2003). Loneliness and social uses of the Internet. Computers in Human Behavior, 19, 659-671. doi:10.1016/S07475632(03)00040-2

Wilson, R.E., Gosling, S.D., \& Graham, L.T. (2012). A review of Facebook research in the social sciences. Perspectives on Psychological Science, 7, 203-220. doi: $10.1177 / 174569161244290$

\section{References}

Voiskunsky, A.E. (1990). Preobrazovanie obshhenija, oposredstvovannogo kompjuterom [Transformation of Computer-Mediated Communication]. Extended abstract of candidate's thesis. Moscow : Lomonosov Moscow State University [in Russian].

Voiskunsky, A.E. (2001). Razvitie rechevogo obshhenija kak rezultat primenenija Interneta [Development of Speech Communication as a Result of Use of the Internet]. Proceedings from SPPPIT '01: Mezhdunarodnaja internet-konferencija na inf.-obrazovatelnom portale www.auditorium/ru «Socialnye i psihologicheskie posledstvija primenenija informacionnyh tehnologij» (20.03-14.05.2001) The International Online Conference on the Information and Educational Portal www.auditorium/ru «Social and Psychological Consequences of the Application of Information Technologies» (20.03-14.05.2001). (pp. 232-242). Moscow [in Russian].

Goroshko, E.I. (2006). Internet-kommunikacii v gendernom izmerenii [Internet Communication in the Gender Dimension]. Vestnik permskogo universiteta "Jazyk - kultura - civilizacija» - Bulletin of the Perm University "Language Culture - Civilization», 3, 219-229 [in Russian].

Goroshko, E.I. (2008). Psiholingvistika Internet-kommmunikacij [Psycholinguistics of Internet Communications]. Voprosy psiholingvistiki - Journal of Psycholinguistics, 7, 5-12 [in Russian].

Lutovinova, O.V. (2009). Lingvokulturologicheskie harakteristiki virtualnogo diskursa. Doctoral dissertation. Federalnoe agentstvo po obrazovaniju, GOU VPO «Volgogradskij gos. ped. un-t» (VGPU), Nauchno-issledovatelskaja lab. «Aksiologicheskaja lingvistika». Volgograd. [in Russian].

Belinskaja, E.P., \& Zhichkina, A.E. (2000). Sovremennye issledovanija virtualnoj kommunikacii: problemy, gipotezy, rezultaty [Modern research of virtual communication: problems, hypothesis, results], Obrazovanie i informacionnaja kultura - Education and Educational Culture (pp. 395-428) [in Russian].

Shevchenko, I.S. (2002). Variativnost samoprezentacii lichnosti v Internet-obshhenii [Person's self-presentation variations in Internet communication]. Candidate's dissertation. Kazanskij Gosudarstvennyj Universitet. Kazan [in Russian].

Pilgun, M.A. (2015). Osnovnye kommunikativnye patterny v russkojazychnoj setevoj srede [Basic Communicative Patterns in the Russian-Language Network Environment]. Voprosy psiholingvistiki - Journal of Psycholinguistics, 2(24), 166-176 [in Russian].

Tikhomirov, O.K. (1993). Informacionnyj vek i teorija L.S. Vygotskogo [The Information Age and the Theory of L.S. Vygotsky]. Psihologicheskij zhurnal - Psychological Journal, 1, 111-119 [in Russian].

Shebanova, V.I. (2014). Diahnostyka osobystisnoi samoprezentatsii khvorykh na nervovu anoreksiiu metodom kontent-analizu [Diagnosing Personal SelfPresentation of Patients with Nerve Anorexia by the Method of Content Analysis]. 
Perspektyvni napriamky rozvytku suchasnykh pedahohichnykh i psykholohichnykh nauk - Promising Directions of the Development of Modern Pedagogical and Psychological Sciences, (pp. 83-87). Kharkiv : Center for Pedagogical Research [in Ukrainian].

Ahn, D., \& Shin, D.-H. (2013). Is the social use of media for seeking connectedness or for avoiding social isolation? Mechanisms underlying media use and subjective wellbeing. Computers in Human Behavior, 29, 2453-2462. doi:10.1016/j. chb.2012.12.022

Boyd, D.M., \& Ellison, N.B. (2008). Social network sites: Definition, history, and scholarship. J. Comput.-Mediat. Commun, 13, 210-230. doi: 10.1111/j.10836101.2007.00393.x

Carr, N.G. (2008). The Big Switch: Rewiring the World, from Edison to Google. New York, London : W.W. Norton \& Company.

Gemius Audience. Internet audience of Ukraine in September 2017 (October 19, 2017). Retrieved from https://www.slideshare.net/LesyaPrus/internet-audience-ofukraine-in-september-2017

Morahan-Martin, J., \& Schumacher, P. (2003). Loneliness and social uses of the Internet. Computers in Human Behavior, 19, 659-671. doi:10.1016/S07475632(03)00040-2

Wilson, R.E., Gosling, S.D., \& Graham, L.T. (2012). A review of Facebook research in the social sciences. Perspectives on Psychological Science, 7, 203-220. doi: $10.1177 / 174569161244290$

Fillips, L., \& Jorgensen, M.V. (2008). Diskurs-analiz. Teorija i metod [Discourse analysis. Theory and method] (Trans.). (2nd ed.). Harkov : Gumanitarnyj centr.

\section{АНОТАЦІЯ}

У статті здійснений теоретико-прикладний аналіз проблем спілкування в соціальних онлайн-мережах. Показано, що завдяки специфіці каналу комунікації формується віртуальна спільнота з унікальними мовними, культурними та психологічними властивостями (при цьому відзначена зміна ландшафту користування інтернет-ресурсами у зв'язку з розгортанням соціально-політичної кризи в Україні). Описаний феномен фрагментарного бриколажного мислення, що виникає внаслідок впливу гіпертекстової структури та інформаційної навантаженості Інтернет-середовища. Характер мережевого спілкування дає підстави говорити про формування особливої форми мовлення - усної за сутністю та друкованої за втіленням. Особистість в онлайн-дискурсі представлена редуковано: як набір продукованих нею текстових $і$ візуальних повідомлень. Описані типові форм комунікативної активності в мережевому середовищі, що мають діагностичне і прогностичне значення. Виділені актуальні перспективи психолінгвістичних досліджень дискурсу соціальних онлайн-мереж: проблема сприйняття та інтерпретації текстових повідомлень; проблема взаємозв'язку між технологічними можливостями каналу комунікації та формами комунікативної поведінки користувачів; 
Psycholinguistic Problem Field of Studies of the Social Online...

проблема самопрезентації та дизайну ефективних повідомлень (що передбачає осмислення себе, власного досвіду і можливостей взаємодії з іншими); проблема адекватного «зчитування» мовної особистості партнера по спілкуванню, розпізнавання маркерів певних психологічних порушень; проблема маніпулятивного та мобілізаційного впливу, необхідності фрормувати навички критичного мислення стосовно сприйнятої інформації, ії фальсифікачії та перекручувань; проблема впливу онлайн-спілкування на окрему особистість, їі світогляд та поведінку, а також на суспільство в цілому; значення інформаційних технологій в онтогенезі мовлення. Окремо постає методологічна проблема розробки і вдосконалення інструментів оцінки поведінки людини в Інтернет-мережі через аналіз текстів.

Ключові слова: інтернет-дискурс, віртуальне спілкування, сочіальна мережа, дизайн онлайн-повідомлення, самопрезентація, маніпуляція, комунікативна етика.

\section{Бочелюк Виталий, Панов Никита. Проблемное поле психолингвистических} исследований дискурса социальных онлайн-сетей

\section{АННОТАЦИЯ}

В статье осуществлен теоретико-прикладной анализ проблем общения в социальных онлайн-сетях. Показано, что благодаря специфике канала коммуникации формируется виртуальное сообщество с уникальными языковыми, культурными и психологическими свойствами (при этом отмечено изменение ландшарта пользования интернетресурсами в связи с разворачиванием социально-политического кризиса в Украине). Описан феномен фрагментарного бриколажного мышления, возникающий вследствие воздействия гипертекстовой структуры и информационной нагруженности Интернет-среды. Характер сетевого общения дает основания говорить о формировании особой формы речи - устной по сути и печатной по воплощению. Личность в онлайн-дискурсе представлена редуцировано: как набор произведенных нею текстовых и визуальных сообщений. Описаны типичные форм коммуникативной активности в сетевой среде, имеющие диагностическое и прогностическое значение. Выделены актуальные перспективы психолингвистических исследований дискурса социальных онлайн-сетей: проблема восприятия и интерпретации текстовых сообщений; проблема взаимосвязи между технологическими возможностями канала коммуникации и формами поведения пользователей; проблема самопрезентации и дизайна эффрективных сообщений (что предполагает осмысление себя, собственного опыта и возможностей взаимодействия с другими); проблема адекватного 
Проблемне поле психолінгвістичних досліджень дискурсу...

"считывания» языковой личности партнера по общению, распознавание маркеров определенных психологических нарушений; проблема манипулятивного и мобилизационного воздействия, необходимости формировать навыки критического мышления относительно воспринятой информации, ее фальсификации и искажений; проблема влияния онлайн-общения на отдельную личность, ее мировоззрение и поведение, а также на общество в целом; значение информационных технологий в онтогенезе речи. Отдельно ставится методологическая проблема разработки и совершенствования инструментов оценки поведения человека в Интернет-сети через анализ текстов.

Ключевые слова: интернет-дискурс, виртуальное общение, социальная сеть, дизайн онлайн-сообщений, самопрезентация, манипуляция, коммуникативная этика. 